\title{
Biodiversity of vascular plants of Kuzbass
}

\author{
Svetlana Sheremetova ${ }^{1, *}$, Irina Khrustaleva $^{1}$ and Peter Stieglbauer $^{2}$ \\ ${ }^{1}$ Federal Research Center of Coal and Coal Chemistry SB RAS 650065, Leningradsky av., 10, \\ Kemerovo, Russia. \\ ${ }^{2}$ PolyDynamic UG, Klostergasse, 5, 04109 Leipzig, Germany
}

\begin{abstract}
The latest vascular plants biodiversity data of Kuzbass region is presented. The species that should be excluded from the Kemerovo region flora list are reported. The species that require further research for making an exclusion from Kuzbass vascular plants species list are mentioned. Additionally, rare species that can already be attributed to disappeared ones from the territory of the region are noted. It is established that there are 1728 species of vascular plants at the present time on the territory of Kuzbass.
\end{abstract}

Information about Kuzbass region flora has being accumulated during 300 years. During this time, periods of active scientific research were combined with relative stagnation time intervals. Before the Kemerovo region herbarium creation, all the materials collected in Kuzbass were sent to herbaria of other regions: St. Petersburg, Tomsk, Novosibirsk and others. [1-2].

Over time, several Kemerovo region herbaria were established - in the Kemerovo State University, in the Novokuznetsk Pedagogical Institute. In the 90s of XX century, a herbarium collection was established on the base of Kuzbass Botanical Garden (KuzBG). Together with the formation of herbarium funds, scientific publications on the floristic composition of certain regions of Kuzbass were accumulating.

In the article dedicated to the researchers of the Kemerovo region flora, I.M. Krasnoborov [2] mentiones that in 1950 A.V. Kuminova [3] noted in her thesis "The Vegetation of the Kemerovo region" that Kemerovo region takes a leading position in the study of the vegetation cover in comparison with other regions of Siberia. And I.M. Krasnoborov states that in the last 50 years after the publication of A.V. Kuminova thesis, Kemerovo region has lost this leadership. In his essay, I.M. Krasnoborov [2] refers to 97 scientific resources, that contain information about the Kemerovo region flora. He also notes that works "The Plant identification guide of the Kemerovo region" [4] creation, published in 2001, was extremely complicated due to low amount of floristic publications on certain groups of plants, and due to herbarium collections separate storage in various repositories all over the country.

The situation has changed significantly thanks to the active work of the KuzBG researchers. By 2021, the bibliography on botanical research in Kuzbass increased by more than 350 works. On the basis of the KuzBG the deep investigation monography "Key

${ }^{*}$ Corresponding author: ssheremetova@,rambler.ru 
botanical territories of the Kemerovo region" under the leadership of A.N. Kupriyanov [5], 2nd and 3rd editions of "The Red Book of the Kemerovo region" [6-7], "The Black Book of the Flora of Siberia" [8], "The Tom River basin: floristical and physical-geographical features" [9] and other fundamental research essays were published.

Thanks to the long-term expeditionary research, conducted by the KuzBG scientists (Buko T.E., Sheremetova S.A., Kupriyanov A.N., Nozhinkov A.E., Khrustaleva I.A., Strelnikova T.O., Manakov Yu.A., Kupriyanov O.A. and others) together with the researches from the Central Siberian Botanical Garden of Siberian Branch of the Russian Academy of Sciences, Tomsk State University, Novokuznetsk Pedagogical Academy, Kemerovo State University (A.L. Ebel, N.N. Lashchinsky, V.A. N.V. Makunina, N.V. Shchegoleva, A.A. Zverev, A.V. Klimov, G.I. Yakovleva and others), the Kuzbass region Herbarium fund was finally established. In 2010, the Herbarium was included into the Index Herbariorum international database with the acronym KUZ. Currently it is represented by the Kemerovo Region section with 20,000 storage samples.

The aim of this work is to analyze the current state of information concerning the Kuzbass vascular plants flora, as well as to discuss the existing problems and prospects of their solution.

In "The Plant identification ..." [4] it is indicated that 1585 species of higher vascular plants belonging to 125 families are registered on the territory of the region. Apparently, there was a typo, as in fact, the monograph contains 1521 species.

Since the publication of "The Plant identification ..." [4], a large number of new species of vascular plants have been noted for the territory of the Kemerovo region. This information was scattered, sometimes in different publications the same species were indicated by different authors. Over the past 20 years, two attempts to summarize the data on floristic finds in Kuzbass [10-11] were arranged. An insignificant part of the species was mistakenly included into the lists of new species, as more detailed studies and checks have shown the incorrectness of the identification. The following species should be excluded from the list of vascular plants growing in the Kemerovo region: Lathyrus krylovii Serg. [12], Adenophora tricuspidata (Fisch. ex Schult.) A. DC. [13-14], Cerasus vulgaris Mill. [15]. Thus, totally 175 new species of vascular plants have been assigned for Kuzbass during the past 20 years.

According to the results of the inventory during the digitization of the collections of the Herbarium of the Kuzbass Botanical Garden (KUZ), it was stated that the fund includes 1629 species, belonging to 552 genera and 122 families. Obviously, the list of species given in "The Plant identification ..." [4] and stored in the fund do not coincide. The reasons for this are the following: (1) newly found species; (2) the critical revision of some taxons by modern systematicum; (3) the absence of some species in the collections of the KUZ Herbarium.

It is necessary to exclude 21 species from the list Kemerovo region species. These are either species not growing currently in the area, or incorrectly identified, or currently not separated as an independent taxon: Alyssum tortuosum Waldst. \& Kit. ex Willd., Artemisia mongolica (Besser) Fisch. ex Nakai, A. santolinifolia Turcz. ex Besser, Aster sibiricus L., Campanula dasyantha M.Bieb., Dactylorhiza balica (Klinge) Orlova, D. cruenta (O.F.Muell.) Soa, D. maculata (L.) Soa, D. meyeri (Reichend. fil.) Aver., D. russowii (Klinge) Holub, Ephedra distachya L., Gagea fragifera (Vill.) E. Bayer et G. Lopez., Hordeum roshevitzii Bowden, Isatis oblongata DC., Paeonia hybrida Pall., Primula sieboldii E. Morren, Rhododendron dauricum L., Spiraea crenata L., Stipa brauneri (Pacz.) Klokov, Vicia multicaulis Ledeb., Viola incisa Turcz.

In "The Plant identification ..." (2001), some species were indicated as "possible to be found on the territory of the region", such as Botrychium virginianum (L.) Sw., Krascheninnikovia ceratoides (L.) Gueldenst., Mitella nuda L., Physochlaina physaloides 
(L.) G.Don, Tephroseris turczaninovii (DC.) Holub. Now their presence is confirmed by the collections stored in the funds of the KUZ Herbarium. For Rubus humulifolius C.A.Mey in "The Plant identification..." [4], a non-existing settlement as a location was mentioned. With our investigation, the presence of this plant on the territory of Kuzbass is confirmed.

There is a group of species indicated in "The Plant identification ..." [4], but currently they are absent in our collections (104 species). This group is very diverse. Some of the rare species we can attribute to the disappeared from the territory of the region. They do not appear in the new collected materials and have not been observed in the region for a long time: Hyssopus ambiguus (Trautv.) Iljin, Primula nutans Georgi [16] (TK!), Trapa natans L.

Some weed species, due to the peculiarities of their life cycle and the specifics of habitats, can not be found in the previously known collection sites: Ambrosia artemisiifolia L., Chorispora tenella (Pall.) DC., Hibiscus trionum L., Salvia verticillata L. Sisyrinchium septentrionale Bicknell [17].

But the overwhelming majority of species of this group require additional research to make a decision on the possibility of excluding (or not excluding) them from the list of species of Kuzbass vascular plants, such as: Astragalus miklaschewskii Basil., Campanula patula L., Erigeron flaccidus (Bunge) Botsch., Festuca brachyphylla Schult. \& Schult., Gentiana ciliata L., Gentiana decumbens L., Gypsophila sericea (Ser.) Krylov, Hedysarum alpinum L., Iris sibirica L., Juncus stygius L., Lamium amplexicaule L., Nardus stricta L., Ophelia diluta (Turcz.) Ledeb., Paraquilegia microphylla (Royle) J.R.Drumm. \& Hutch., Pedicularis anthemifolia Fisch. ex Colla, Pedicularis dasystachys Schrenk, Plantago scabra Moench, Ptilagrostis mongholica (Turcz. ex Trin.) Griseb., Pyrethrum pulchrum Ledeb., Saussurea foliosa Ledeb., Saxifraga melaleuca Fisch. ex Spreng., Scorzonera purpurea L., Trifolium spadiceum L., Vaccaria hispanica (Mill.) Rauschert, Verbascum phoeniceum L., Veronica spuria L. and others.

A separate category is represented by cultivated species found outside the cultivation areas. Their nomenclature has not been worked out yet and indications in the floristic works are very rare [18]. But the potential for some of these species to take stable positions in the region flora is steadily growing, so the inclusion of this category to the list will lead to an increase in the total amount of vascular plant species in Kuzbass.

Thus, to the date we can indicate 1738 species of vascular plants for the Kemerovo region. We assume that after receiving more data information concerning the 100 species that still require additional investigation and confirmation, the total amount of species will change.

The studies is carried out according to of the state assignment of the Russian Foundation for Basic Research and Administration of Kemerovo Region (grant №20-44-420007 r_a), and within the State assignment №0286-2021-0010 (state registration no. AAAA-A21-121011590010-5), on the base of the USU №508667 "Herbarium of the Kuzbass Botanical Garden (KUZ)".

\section{References}

1. I. Borodin, Collectors and collections on the flora of Siberia (Saint Petersburg, 1908)

2. I.V. Krasnoborov, Botanical research in Siberia and Kazakhstan, 12, 134-147 (2006)

3. A.V. Kuminova, The Vegetation of the Kemerovo region (Novosibirsk, 1950)

4. The Plant identification guide of the Kemerovo region (Novosibirsk, 2001)

5. The Important plant areas of Kemerovo region (Kemerovo, 2009)

6. The Red Book of the Kemerovo region, 1 (Kemerovo, 2000)

7. The Red Book of the Kemerovo region, 2 (Kemerovo, 2021)

8. The Black Book of the Flora of Siberia (Novosibirsk, 2016) 
9. S.A.Sheremetova, R.T. Sheremetov, The Tom River basin: floristical and physical-geographical features (Novosibirsk, 2020)

10. S.A. Scheremetova, A.L. Ebel, T.E. Buko, Turczaninowia, 14(1), 65-74 (2011)

11. S.A. Scheremetova, I.A. Khrustaleva, A.N. Kupriyanov, T.O. Strelnikova, G.I. Jakovleva, Bot. Journ.,106, 63-69 (2021)

12. T.E. Buko, S.A. Sheremetova, The floristic finding in the Kemerovo region, Collection of materials of the scientific and practical conference "Trends and factors of development of the agro-industrial complex of Siberia", 134-139 (Kemerovo, 2005)

13. T.E. Buko, Botanical research in Siberia and Kazakhstan, 8, 35-53 (2002)

14. S.A. Scheremetova, T.E. Buko, A.L. Ebel, Botanical research in Siberia and Kazakhstan, 15, 91-93 (2009)

15. A.N. Kupriyanov, K.S. Lazarev, Bull. Main Bot. Garden, 198, 30-34 (2012)

16. P.N. Krylov, Flora of Western Siberia (Tomsk, 1927-1949)

17. O.V. Barysheva, G.I. Jakovleva, Bot. Journ., 86 (4), 156-159 (2001)

18. A.L. Ebel, Conspectus of the flora of the North-Western part of the Altai-Sayan region (Kemerovo, 2012) 